\title{
Habitat Preferences of Spotted Seatrout, Cynoscion nebulosus, in Coastal Louisiana: A Step Towards Informing Spatial Management in Estuarine Ecosystems
}

\author{
Pamela S.D. MacRae ${ }^{1,2, *}$ and James H. Cowan Jr. ${ }^{1}$ \\ ${ }^{1}$ Louisiana State University, Department of Oceanography and Coastal Sciences, Energy, Coast and Environment Build- \\ ing, Baton Rouge, LA 70803, USA \\ ${ }^{2}$ Current address: PBS\&J Environmental Sciences Division, 2639 North Monroe St. Bldg. C, Tallahassee FL 32303, USA
}

\begin{abstract}
Louisiana wetlands are disappearing at a dramatic rate, providing an impetus for identifying the relative value to fishes of a matrix of estuarine habitat types. The distribution, relative abundance, biomass, and length of spotted seatrout, Cynoscion nebulosus (Cuvier) were examined in Barataria Bay, Louisiana, in relation to habitat type and abiotic variables. Spotted seatrout were collected from three sites located along a salinity gradient. Each site contained the three habitat types of interest: marsh edge, soft bottom and oyster shell, and were sampled monthly from May 2003 to May 2004 with gillnets. Habitat preference of spotted seatrout was not easily defined by habitat type alone, but rather their distribution, relative abundance, biomass and length distribution were influenced by a combination of habitat type and abiotic variables. These results suggest that habitat type and abiotic properties of the water act together to provide a diverse range of available habitats important to spotted seatrout. Despite the importance of incorporating habitat in fisheries management, it may be that a combination of habitats and their spatial arrangement, as well as abiotic variables, contribute to the value of estuarine habitats in support of fisheries productivity. Thus, efforts to ensure future fisheries productivity of spotted seatrout fisheries in Louisiana will likely be maximized by managing the spatial integrity of multiple habitat types as opposed to focusing on any single type.
\end{abstract}

Keywords: Essential fish habitat, wetlands, oyster reef, spotted seatrout, coastal louisiana.

\section{INTRODUCTION}

Louisiana wetlands are disappearing at a dramatic rate, accounting for about $90 \%$ of the wetland loss in the United States [1,2]. The Barataria-Terrebonne Estuarine Basin (BTEB), in Louisiana, currently accounts for about $60 \%$ of wetland loss in Louisiana and is expected to account for about $80 \%$ by 2050 [3]. This loss may be detrimental to fishes and macroinvertebrates that rely on wetlands at some point in their life history [4-7] and habitat fragmentation in estuaries can alter ecosystem health, dynamics and productivity [8]. Despite observed habitat alterations in coastal Louisiana, fisheries in this region appear to be resilient [9], although how long this can last is uncertain.

Given the regional focus on wetland habitat loss, it is easy to lose sight of the fact that most estuaries have a variety of habitats that exist in a mosaic [10] and that variations in the landscape such as habitat structure and abiotic factors that vary temporally and spatially $[8,11-13]$ provide a complex environment for associated mobile species. Physi$\mathrm{cal} / \mathrm{chemical}$ properties of the estuarine waters of Barataria Bay vary along a north to south salinity gradient which is influenced by freshwater input, tides, and wind, and with water temperatures that varies seasonally, and three habitat types dominate estuaries in Louisiana: marsh (largely Spartina sp.), soft bottom (mud/sand) and intertidal oyster

*Address correspondence to this author at the PBS\&J Environmental Sciences Division, 2639 North Monroe St. Bldg. C, Tallahassee FL 32303, USA; Tel: 850-580-7831; Fax: 850-575-1169;

E-mail: psdmacrae@pbsj.com reef/shell. The value of marshes [4-6] and oyster reef/shell habitat [14-16] as nursery, feeding and breeding habitat for fish is well recognized. However, the relative value of these habitats and how they compare to each other and to soft bottom habitat is poorly known.

Numerous studies have shown that the density of fish differs in relation to abiotic variables [17-20] and among habitat types, many of which have focused on vegetated versus non-vegetated habitats $[5,18,19,21]$. A few studies have focused on the importance of oyster shell habitat and how it compares to adjacent soft bottom habitats $[15,16,22,23]$ and few have compared oyster shell to both soft bottom and vegetated habitats [7, 24, 25]. However, habitat specific use has not been documented for many estuarine species of fish in the northern Gulf of Mexico [7], and little is known about how fish use of marsh edge, soft bottom and oyster shell compare when all habitats occur together in coastal Louisiana.

The Sustainable Fisheries Act, a 1996 amendment to the Magnuson-Stevens Fishery Conservation and Management Act, mandated a fishery management approach that focused on the protection and conservation of habitat important to finfish and shellfish. This included a call for the description and identification of essential fish habitat (EFH), defined as 'those waters and substrate necessary to fish for spawning, breeding, feeding or growth to maturity,' for federally managed fish species. The National Marine Fisheries Service (NMFS) later defined four levels of data needed to describe and identify EFH: 1) distributional data; 2) density or rela- 


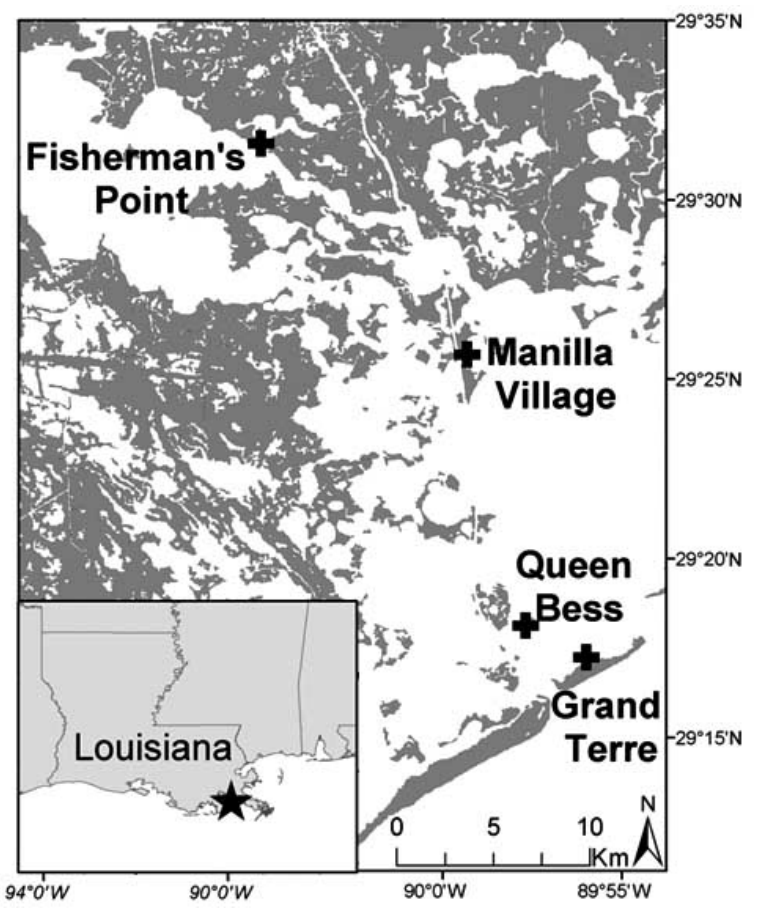

Fig. (1). Map of Barataria Bay, Louisiana, and sampling sites: Grand Terre, Queen Bess, Manilla Village and Fisherman's Point.

tive abundance by habitat type; 3) habitat-related growth, reproduction and survival; and 4) productivity of different habitats. This call to attention of the importance of habitat in fishery management has since prompted many fisheries managers outside of federal fisheries to identify EFH within their waters, particularly for fishes of recreational and economic importance. In doing so, it is now recognized that spatial complexity within and among multiple habitats types in marine ecosystems is likely more important than the presence or absence of any single habitat $[26,27]$.

In Louisiana, the spotted seatrout, Cynoscion nebulosus (Cuvier) is one of the most highly prized recreational finfish species. Spotted seatrout are estimated to be $90 \%$ of the total recreational/commercial harvest in Louisiana [28], with an estimated 10 million harvested in Louisiana inland waters in 2008 [29]. Spotted seatrout, an estuarine dependant species [30], spends much of its life in or near estuarine environments [31]. Spotted seatrout are known to be associated with numerous habitats including seagrass, submerged aquatic vegetation, marsh edge, interior marsh, oyster reef/shell, sand, silt and organic substrate habitats [7, 32-34], although which of these habitats are essential to this species is unknown. Bortone [35] states that the least well documented aspect of spotted seatrout life history is habitat utilization, and that additional studies on habitat preferences are needed. Despite this, a variety of artificial reef projects have begun in coastal Louisiana on the basis of anecdotal evidence that spotted seatrout prefer oyster shell habitat to other available habitats. However, there is little evidence supporting the habitat preference of oyster shell to other available habitats by spotted seatrout in this region, although they are likely essential for some species [15].

The research presented herein is part of a larger cooperative project between Louisiana State University and the
Louisiana Department of Wildlife and Fisheries to identify $\mathrm{EFH}$ of recreational important species in Barataria Bay. Despite the fact that Louisiana fisheries appear to be resilient to significant changes in their habitats [9], the dramatic loss of fish habitat in the BTEB, and the ecological and economic importance of fisheries in this region validate a need to address habitat use of fishes in this region, and to incorporate this information in the spatial management of estuarine habitats. The objective of this project was to examine the presence, relative abundance, biomass and length distribution of spotted seatrout among marsh edge, soft bottom and oyster shell habitats in Barataria Bay, Louisiana, and to relate these measures to abiotic variables, as a step towards informing spatial management in estuarine ecosystems.

\section{MATERIALS AND METHODOLOGY}

\section{Study Location}

All collections were made in Barataria Bay, part of the BTEB in coastal Louisiana (Fig. 1). The BTEB encompasses an area of approximately 16, 575 square kilometers within the Mississippi Deltaic Plain, with an average depth of only $2.3 \mathrm{~m}$ [36]. The basin is bordered by the Mississippi River to the east, the East Atchafalaya Basin Levee and Atchafalaya River to the west and the Gulf of Mexico to the south. Three sites within Barataria Bay were selected for collections: Fisherman's Point (oligohaline), Manilla Village (mesohaline), and Grand Terre (polyhaline). These sites were located along a salinity gradient and each contained the three habitat types of interest: marsh edge, soft bottom (mud/sand) and oyster shell. An exception to this was the Grand Terre site, which did not have oyster shell habitat. Therefore Queen Bess, a nearby location, was chosen to represent the oyster shell habitat for the polyhaline site. Although shell density differed at the three sites sampled, the within site variability was the comparison of interest. Klein digital sidescan sonar was used in an earlier study to differentiate oyster shell bottom from soft bottom (unpublished data). The swath format of the side-scan sonar provided a two dimensional acoustic image of bottom hardness (reflectance), surface texture (roughness) and topography. Habitat specific sampling locations were chosen from these side-scan surveys. In addition, SCUBA collections of bottom sediments were made to confirm the bottom type of habitats.

\section{Sampling Protocol}

Monthly sampling began in May 2003 and was completed in May 2004, with the exception of all sites in December 2003 and Fisherman's Point in November, which were not sampled due to inclement weather. Abiotic properties of the water including: water temperature $\left({ }^{\circ} \mathrm{C}\right)$, dissolved oxygen $\left(\mathrm{mg} \mathrm{l}^{-1}\right)$ and salinity (ppt), were collected at each site on each sampling trip. Data were collected about $30 \mathrm{~cm}$ below the water surface with an YSI model 85. Abiotic data were collected only at the site level given the close proximity of habitat types within each site. Spotted seatrout were collected with a $46.5 \mathrm{~m} \times 2.5 \mathrm{~m}$ gill net in the soft bottom and oyster shell habitat where the water depth was $\leq 2.5 \mathrm{~m}$, and with a $46.5 \mathrm{~m} \times 1.25 \mathrm{~m}$ gill net in the marsh edge habitat where the water was shallower at the marsh perimeter at $\leq 1.25 \mathrm{~m}$. All nets consisted of five $9.3 \mathrm{~m}$ panels, with the following bar mesh sizes: $1.27,1.91,2.54,3.18$ and 3.81 

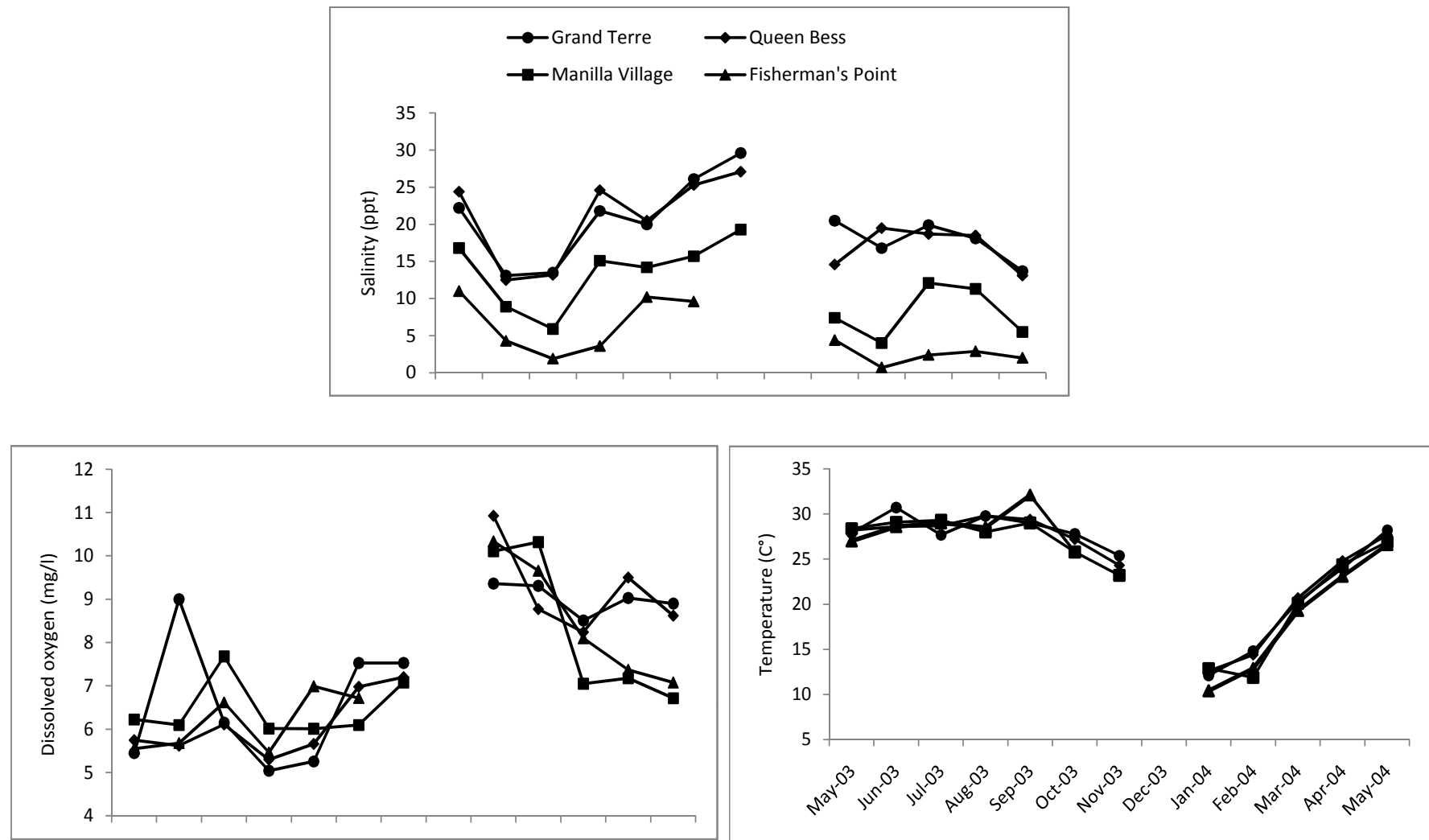

Fig. (2). Plots of water temperature $\left({ }^{\circ} \mathrm{C}\right)$, dissolved oxygen $(\mathrm{mg} / \mathrm{l})$ and salinity (ppt) at sampling sites Grand Terre, Queen Bess, Manilla Village and Fisherman's Point between May 2003 and May 2004.

$\mathrm{cm}$. One gill net was set per habitat type per site for one hour. Spotted seatrout were collected after one hour; then these nets were reset for another hour to replicate the sample in time. Fish collected were put in an ice slurry with MS 222, and later frozen. In the laboratory spotted seatrout were weighed to the nearest tenth of a gram and measured for standard length (SL) to the nearest tenth of a centimeter.

\section{Statistical Analysis}

Two-way analysis of variance (ANOVA) with Tukey HSD post-ANOVA tests (alpha $=0.05$ ) were used to independently compare water temperature, dissolved oxygen and salinity among sites and months. Note that month was nested within year for this analysis because of the overlap between May 2003 and May 2004. Five-factor ANOVA with Tukey HSD post-ANOVA tests (alpha $=0.05$ ) were used to independently compare catch per unit effort (CPUE), biomass and standard length of spotted seatrout, pooled across months, among habitats, sites, water temperature, dissolved oxygen and salinity. A backward stepwise approach was used in this analysis, thus insignificant interactions were excluded from the model to maximize the power of the ANOVA. Prior to ANOVA CPUE, biomass and standard length data were tested for normality (Shapiro-Wilks) and homogeneity of variance (Levene's test); data that did not meet these assumptions were $\log (\mathrm{x}+1)$ transformed. Finally, a logistic regression, alpha $=0.05$, was used to predict the presence/absence of spotted seatrout based on habitat, site, temperature, dissolved oxygen and salinity. All analyses were run with SAS [37]. Due to time constraints and selec- tion criteria of sampling sites, treatments were not replicated and therefore caution should be used when extrapolating results to areas other than those sampled during this study [38].

\section{RESULTS}

\section{Abiotic Variables}

Water temperature was highest between May and October, and ranged between $10.4^{\circ} \mathrm{C}$ and $32.1^{\circ} \mathrm{C}$ during this study (Fig. 2). Temperature was inversely related to dissolved oxygen, which was highest between January and April, and ranged between $5.0 \mathrm{mg} \mathrm{l}^{-1}$ and $10.9 \mathrm{mg} \mathrm{l}^{-1}$ (Fig. 2). Temperature and dissolved oxygen did not differ significantly among sites $(p=0.06, p=0.68$; Table 1), but did differ among months sampled ( $\mathrm{p}<0.05, \mathrm{p}<0.05$ respectively, Table $\mathbf{1}$ ). Salinity varied seasonally and ranged between $0.7 \mathrm{ppt}$ and 29.6 ppt (Fig. 2). Salinity differed significantly among sites and months sampled ( $\mathrm{p}<0.05, \mathrm{p}<0.05$; Table 1). Salinity was not significantly different between Grand Terre and Queen Bess sites, which validated the inclusion of Queen Bess as a substitute shell habitat for the Grand Terre site, although salinity did increase significantly among sites located along the salinity gradient (oligohaline, Fisherman's Point, mesohaline, Manilla Village, and polyhaline, Grand Terre/Queen Bess.

\section{Spotted Seatrout}

We collected 176 spotted seatrout between May 2003 and May 2004. Of these, 90 were collected from the Grand 
Table 1. Results of the Two-Way ANOVA Comparing Water Temperature $\left({ }^{\circ} \mathrm{C}\right)$, Dissolved Oxygen (mg/l) and Salinity (ppt) by Site and Month(year)

\begin{tabular}{|c|c|c|c|c|c|}
\hline & & d.f. & F & MS & 2.26 \\
\hline \hline Temperature $\left({ }^{\circ} \mathrm{C}\right)$ & Site & 3 & 2.69 & 0.06 \\
\hline & Month(year) & 11 & 177.48 & 149.17 & $<0.05$ \\
\hline Dissolved oxygen $(\mathrm{mg} / \mathrm{l})$ & Site & 3 & 0.50 & 0.36 & 0.68 \\
\hline Salinity (ppt) & Month(year) & 11 & 11.95 & 8.52 & $<0.05$ \\
\hline & Site & 3 & 111.68 & 518.92 & $<0.05$ \\
\hline
\end{tabular}

Table 2. Summary of Total Catch, Mean Biomass (g) and Mean Standard Length (cm) of Spotted Seatrout by Site and Habitat, as well as an Overall Mean of Biomass (g) and Standard Length $(\mathrm{cm})$ for each Site and Habitat

\begin{tabular}{|c|c|c|c|c|c|}
\hline & & GT/QB & MV & $\mathbf{F P}$ & Mean \\
\hline \multirow[t]{2}{*}{ Total Catch } & Marsh edge & 30 & 6 & 5 & \\
\hline & Oyster shell & 22 & 41 & 7 & \\
\hline \multirow[t]{3}{*}{ Mean Biomass(g) } & Marsh edge & 286.2 & 81.7 & 92.0 & 229.0 \\
\hline & Oyster shell & 373.5 & 221.2 & 152.4 & 263.8 \\
\hline & Overall Mean & 258.7 & 207.5 & 176.8 & \\
\hline \multirow[t]{2}{*}{ Mean Standard Length $(\mathrm{cm})$} & Marsh edge & 26.6 & 16.4 & 17.7 & 23.8 \\
\hline & Soft Bottom & 22.5 & 24.2 & 28.1 & 23.4 \\
\hline
\end{tabular}

GT/QB = Grand Terre/Queen Bess, MV = Manilla Village, FP = Fisherman's Point

Terre/Queen Bess site (30 at marsh edge, 38 at soft bottom and 22 at oyster shell), 71 were collected from Manilla Village (6 at marsh edge, 24 at soft bottom and 41 at oyster shell) and 15 were collected from Fisherman's Point (5 at marsh edge, 3 at soft bottom and 7 at oyster shell, Tables 2 and 3). Catch per unit effort did not differ significantly between habitat types $(p=0.21$, Table 4$)$. In general, more spotted seatrout were collected at the oyster shell habitat followed by soft bottom and then marsh edge habitats. Catch differed significantly among sites ( $p<0.01$, Table 4). Catch per unit effort was significantly higher at Grand Terre/Queen Bess and Manilla Village than at Fisherman's Point. Catch per unit effort was also significantly related to temperature $(\mathrm{p}=0.01$, Table 4) and salinity $(\mathrm{p}=0.04$, Table 4), and increased as both temperature and salinity increased (Fig. 3). There was no significant relationship between CPUE and dissolved oxygen $(\mathrm{p}=0.86$; Table 4$)$.

The mean biomass and standard length of spotted seatrout differed significantly among habitats $(\mathrm{p}<0.05$ and $\mathrm{p}$ $<0.05$ respectively, Table 4$)$ and among sites $(\mathrm{p}<0.05$ and $\mathrm{p}$ $<0.05$ respectively, Table 4 ), but with a significant interaction between site and habitat $(\mathrm{p}<0.05$, Table 4). The mean biomass and mean standard length of spotted seatrout were similar among habitats (pooled among sites) and among sites (pooled among habitats) (Table 2). However, spotted seatrout along the marsh edge were on average smaller than those collected over soft bottom and oyster shell habitats at both the Manilla Village and Fisherman's Point sites, although this was not the case at the Grand Terre/Queen Bess site. At the Grand Terre/Queen Bess site a large number of large gravid females were collected along the marsh edge, which increased the average biomass and standard length of spotted seatrout collected at that habitat. Despite this observed trend in differences in size among habitats at two of the sites, the range in standard lengths of spotted seatrout captured along the marsh edge $(9.8-34.5 \mathrm{~cm})$ were similar those observed over soft bottom $(9.3-36.1 \mathrm{~cm})$ and oyster shell $(15.5-32.3 \mathrm{~cm})$ habitats when pooled among sites. When pooled among habitats, spotted seatrout were on average larger at Grand Terre/Queen Bess $(17.1-36.1 \mathrm{~cm})$, followed by Manilla Village $(9.3-32.8 \mathrm{~cm})$ and Fisherman's Point $(11.0-32.3 \mathrm{~cm})$ (Table 2). Biomass and standard length of spotted seatrout were also significantly related to water temperature $(\mathrm{p}<0.05, \mathrm{p}=0.01$, Table 4$)$, with bio- 
Table 3. Mean CPUE Values \pm Standard Error of Spotted Seatrout (Number per 1 hr Gill Net Set) Collected at Three Sites among Three Habitat Types from May 2003 through May 2004 in Barataria Bay, Louisiana

\begin{tabular}{|c|c|c|c|c|c|c|c|c|c|}
\hline Site & GT/QB & GT/QB & GT/QB & MV & MV & MV & FP & FP & FP \\
\hline June & $2.0 \pm 0$ & $1.5 \pm 1.5$ & $1.0 \pm 1.0$ & & $1.5 \pm 0.5$ & $2.0 \pm 1.0$ & & $1.0 \pm 0$ & $0.5 \pm 0.5$ \\
\hline July & $5.0 \pm 5.0$ & & $1.0 \pm 0$ & & $1.5 \pm 0.5$ & $1.0 \pm 1.0$ & & & $0.5 \pm 0.5$ \\
\hline September & & $4.0 \pm 3.0$ & & $0.5 \pm 0.5$ & $0.5 \pm 0.5$ & & $2.0 \pm 1.0$ & & \\
\hline \multicolumn{10}{|l|}{ October } \\
\hline November & & & & $1.5 \pm 1.5$ & & & NS & NS & NS \\
\hline December & NS & NS & NS & NS & NS & NS & NS & NS & NS \\
\hline March & & & & & $0.5 \pm 0.5$ & $1.5 \pm 1.5$ & & & $0.5 \pm 0.5$ \\
\hline April & $0.5 \pm 0.5$ & & $1.0 \pm 1.0$ & & $1.5 \pm 0.5$ & $3.0 \pm 1.0$ & $0.5 \pm 0.5$ & & \\
\hline May & $2.0 \pm 2.0$ & $5.0 \pm 3.0$ & $2.5 \pm 1.5$ & & $1.0 \pm 1.0$ & $1.0 \pm 1.0$ & & $0.5 \pm 0.5$ & $0.5 \pm 0.5$ \\
\hline
\end{tabular}

GT/QB = Grand Terre/Queen Bess, MV = Manilla Village, FP = Fisherman's Point

Blank cells indicate an absence of spotted seatrout

NS indicates sites and habitats that were not sampled due to inclement weather

mass and standard length increasing as water temperature increased (Fig. 4).

Logistic regression was used to predict the probability of detecting the presence of spotted seatrout by site, habitat, temperature, dissolved oxygen and salinity. The model was significant at alpha $=0.05$, and included habitat, temperature and the habitat by temperature interaction, with an odds ratio of 1.55 to 1.14 (Table 5). The predicted probabilities of presence based on habitat and temperature are presented in Figs. (5) and (6) respectively. The probability of detection increased from $86.0 \%$ to $99.8 \%$ to $99.9 \%$ from the marsh edge to soft bottom to oyster shell habitat. The probability of detection for spotted seatrout also increased as water temperature increased. As water temperature increased from $10.4^{\circ} \mathrm{C}$ to $14.8^{\circ} \mathrm{C}$, the probability of detection increased from $32.6 \%$ to $82.6 \%$. The probability of detecting a spotted seatrout reached $98 \%$ at $19.3^{\circ} \mathrm{C}$ and $99.0 \%$ as the water temperature reached $24^{\circ} \mathrm{C}$ and greater. The significant interaction between habitat and temperature suggests that spotted seatrout occur more frequently over soft bottom or oyster shell habitats compared to the marsh edge, when the water temperature is $24.0^{\circ} \mathrm{C}$ and greater.

\section{DISCUSSION}

In this study, spotted seatrout showed no consistent pattern of habitat selection among habitats, although this was not consistent among sites sampled. Total catch was greater over the oyster shell habitat at Manilla Village, however this was not true at Grand Terre/Queen Bess or Fisherman's Point where catch was similar among habitats. These results are similar to Harding and Mann [16] who found that catches of $C$. nebulosus were similar across habitats sampled in the Piankatank River, Virginia, which included oyster shell reef, oyster shell bar and sand bar. However, it has been suggested that oyster reefs may be an important long-term habitat for reef residents, facultative residents and juveniles of some transient species [15]. A study by Coen et al. [15] concluded that the utilization of oyster reef habitats by commercially, recreationally and economically important species makes this habitat type essential, but the functional relationship remains to be evaluated. Lehnert and Allen [22] found that subtidal oyster shell habitats supported a more diverse and abundant demersal fish population than nearby soft bottom habitats. This may be because oyster shell habitats provide greater structural complexity than adjacent soft bottom habitats and because more complex habitats offer a greater amount of refuge and are often selected over less complex habitats, especially in the presence of predators [39].

Perret et al. [32] tied the distribution of spotted seatrout to food availability and stated that spotted seatrout are likely found in any area offering suitable salinity and temperature regimes with sufficient prey availability. A review of factors influencing habitat selection of fishes in marsh ecosystems by Craig and Crowder [40] suggests that habitat selections of organisms during ontogeny are an integrated response to their biotic and abiotic environment, presumably resulting in the selection of habitats that enhance fitness. This appears to be true in this study, given that differences in relative abundance of spotted seatrout in this study were explained by both abiotic variables and physical habitat structure. The relative abundance of spotted seatrout increased as tempera- 
Table 4. Results from the Two-Way ANOVA Comparing CPUE, Biomass (g) and Standard Length (cm) of Spotted Seatrout by Habitat, Site, and in Relation to Water Temperature $\left({ }^{\circ} \mathrm{C}\right)$, Dissolved Oxygen 9mg/l) and Salinity (ppt)

\begin{tabular}{|c|c|c|c|c|c|}
\hline & & d.f. & $\mathbf{F}$ & MS & p-value \\
\hline \multirow[t]{6}{*}{ CPUE } & Habitat & 2 & 1.58 & 0.50 & 0.21 \\
\hline & Site & 2 & 7.58 & 2.38 & $<0.05$ \\
\hline & Temperature $\left({ }^{\circ} \mathrm{C}\right)$ & 1 & 5.65 & 1.79 & 0.02 \\
\hline & Dissolved oxygen (mg/l) & 1 & 0.03 & 0.01 & 0.86 \\
\hline & Salinity (ppt) & 1 & 4.43 & 1.39 & 0.04 \\
\hline & Site $\mathrm{x}$ habitat & 4 & 1.96 & 0.62 & 0.10 \\
\hline \multirow[t]{6}{*}{ Biomass (g) } & Habitat & 2 & 19.96 & 6.26 & $<0.05$ \\
\hline & Site & 2 & 5.24 & 1.83 & $<0.05$ \\
\hline & Temperature $\left({ }^{\circ} \mathrm{C}\right)$ & 1 & 14.78 & 5.15 & $<0.05$ \\
\hline & Dissolved oxygen (mg/l) & 1 & 3.14 & 1.09 & 0.08 \\
\hline & Salinity (ppt) & 1 & 1.76 & 0.61 & 0.19 \\
\hline & Site $\mathrm{x}$ habitat & 4 & 14.76 & 5.14 & $<0.05$ \\
\hline \multirow[t]{6}{*}{ Standard Length $(\mathrm{cm})$} & Habitat & 2 & 13.71 & 262.88 & $<0.05$ \\
\hline & Site & 2 & 5.02 & 96.32 & $<0.05$ \\
\hline & Temperature $\left({ }^{\circ} \mathrm{C}\right)$ & 1 & 6.92 & 132.61 & 0.01 \\
\hline & Dissolved oxygen (mg/l) & 1 & 3.14 & 60.11 & 0.08 \\
\hline & Salinity (ppt) & 1 & 3.26 & 62.57 & 0.07 \\
\hline & Site $\mathrm{x}$ habitat & 4 & 12.43 & 238.28 & $<0.05$ \\
\hline
\end{tabular}

CPUE and Biomass Transformed as $\log (\mathrm{x}+1)$

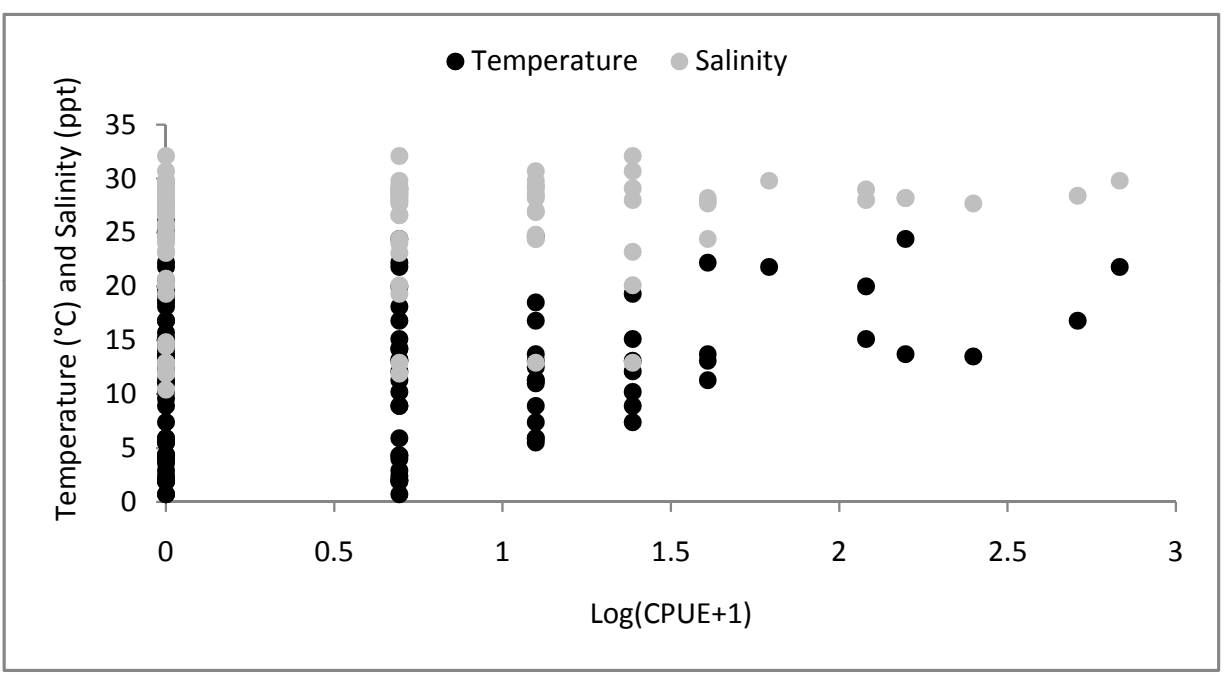

Fig. (3). The relationship between water temperature $\left({ }^{\circ} \mathrm{C}\right)$ and salinity (ppt) and $\log (\mathrm{CPUE}+1)$ of spotted seatrout collected from marsh edge, soft bottom and oyster shell habitats located along a salinity gradient in Barataria Bay, Louisiana between May 2003 and May 2004.

ture and salinity increased, and was greatest at the mesohaline and polyhaline sites. These results are similar to studies by Kostecki and Fore [41] and Minello [7], which found that spotted seatrout were more abundant in mesohaline and polyhaline portions of estuaries as compared to oligohaline portions and during warmer months. While the relative abundance of spotted seatrout in this study did not depend upon dissolved oxygen concentrations in the water, this was likely due to the fact that dissolved oxygen never dropped below intolerable levels during sampling and therefore was never at levels that would restrict habitat use by spotted seatrout [42]. It is also possible that the catchability of spotted seatrout in the gill nets was influenced by spatial and temporal differences in the abiotic variables. Catch in gill 


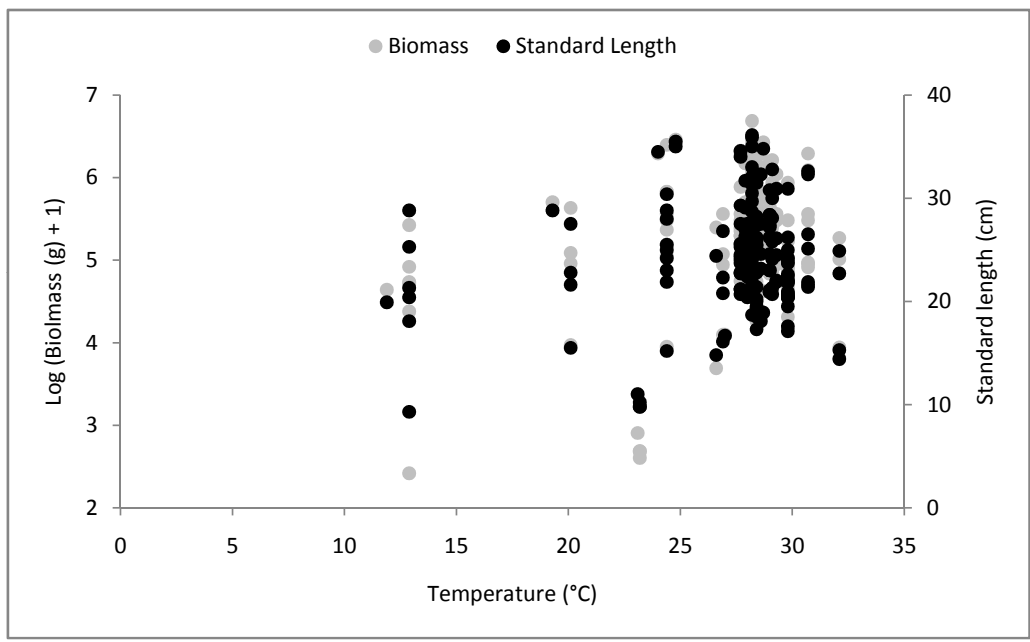

Fig. (4). The relationship between water temperature $\left({ }^{\circ} \mathrm{C}\right)$ and $\log ($ Biomass $(\mathrm{g})+1)$ and standard length $(\mathrm{cm})$ of spotted seatrout collected from marsh edge, soft bottom and oyster shell habitats located along a salinity gradient in Barataria Bay, Louisiana between May 2003 and May 2004.

Table 5. Results from the Logistic Regression of Spotted Seatrout and Variables Significant at the Alpha=0.05

\begin{tabular}{|c|c|c|c|c|}
\hline & Chi-square & d.f. & p-value & Odds Ratio Estimate \\
\hline \hline Model & 11.30 & 4 & $<0.05$ & 1.55 \\
\hline Habitat & 7.87 & 1 & $<0.05$ & 1.14 \\
\hline Temperature & 9.80 & 1 & $<0.05$ & 0.01 \\
\hline Habitat x temperature & 6.82 & 1 & & \\
\hline
\end{tabular}

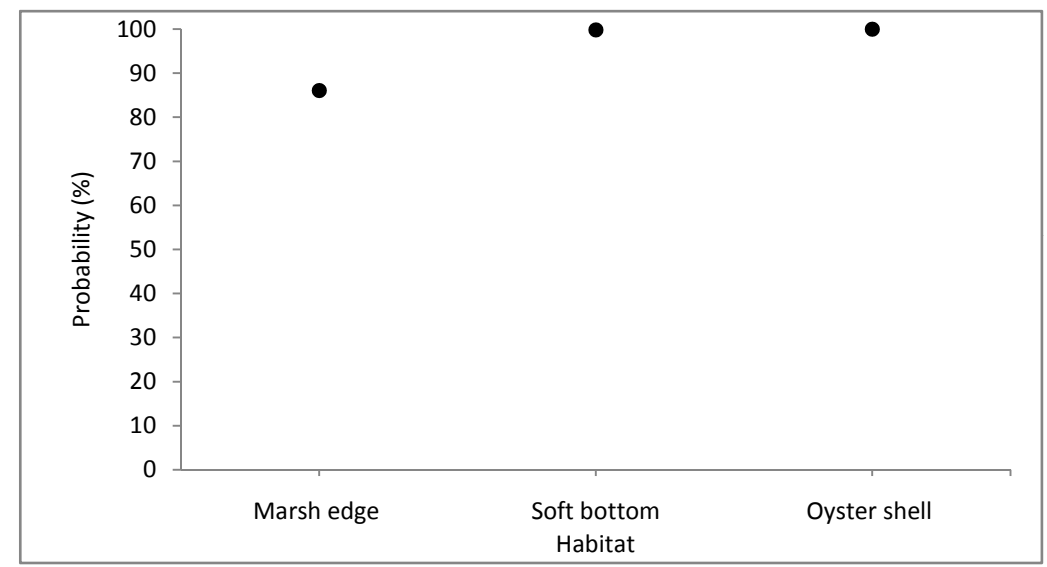

Fig. (5). Plot of logistic regression of spotted seatrout presence/absence among marsh edge, soft bottom and oyster shell habitats located along a salinity gradient in Barataria Bay, Louisiana between May 2003 and May 2004. Closed circles represent predicted probability of detecting a spotted seatrout at a given habitat.

nets is known to be affected by numerous variables including water temperature, time of day, water level fluctuations, turbidity and currents [43]. Moreover, catches in gill nets also are affected by seasonal patterns in the movement and distribution of fishes that occur as a result of spawning activity, habitat requirements and food availability [44]. Thus fewer spotted seatrout may have been collected in the winter because of reduced catchability if spotted seatrout moved less or more slowly when the water temperature was lower.
Body size of fish can play a large role in determining fish-habitat interactions [45] and fish often exhibit ontogenetic habitat shifts [46]. The smallest mesh size of the gill nets in this study was $1.27 \mathrm{~cm}$ stretched mesh, therefore the gill net was not selecting for fish as small as newly settled spotted seatrout. None-the-less, young-of-the-year spotted seatrout $(\geq 9.3 \mathrm{~cm} \mathrm{SL})$ were collected in this study. Therefore, while we cannot discuss the importance of marsh edge habitat to newly settled spotted seatrout, results indicate that 


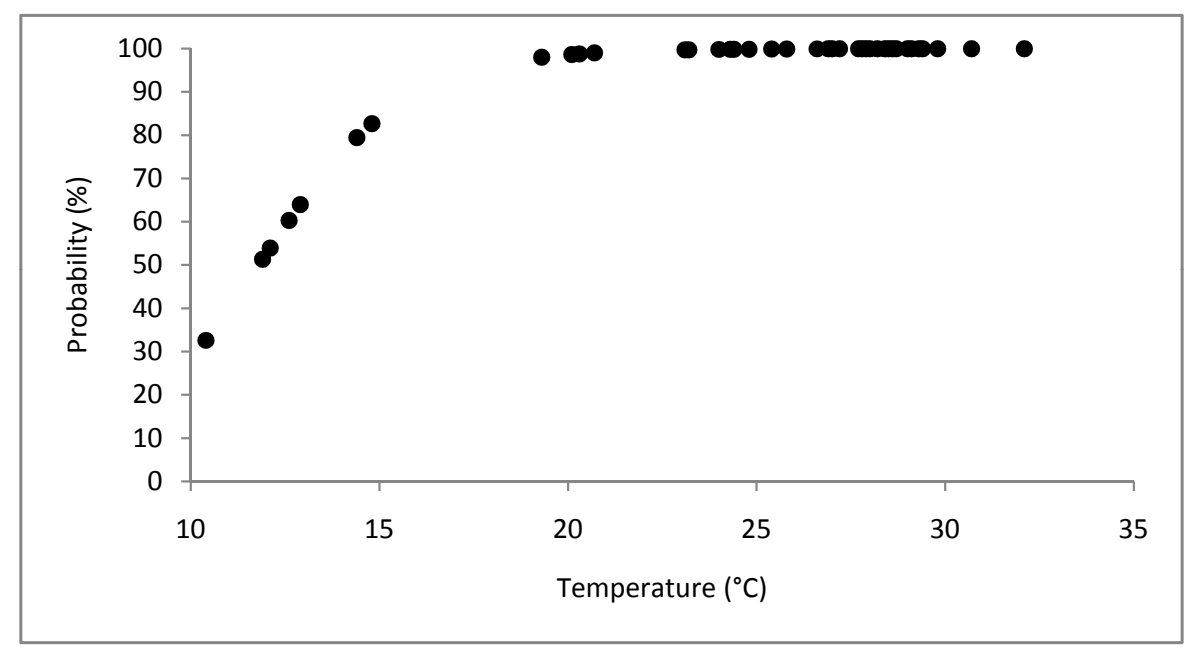

Fig. (6). Plot of logistic regression of spotted seatrout presence/absence by water temperature $\left({ }^{\circ} \mathrm{C}\right)$ among marsh edge, soft bottom and oyster shell habitats collected among sites located along a salinity gradient in Barataria Bay, Louisiana between May 2003 and May 2004. Closed circles represent predicted probabilities of detecting a spotted seatrout at a given temperature.

there was a trend to catch smaller spotted seatrout near the marsh edge compared to soft bottom and oyster shell habitats at two of the sites sampled. This is supported by Birdsong [47] who commonly collected young-of-year spotted seatrout along the marsh edge in seine collections in Barataria Bay, Louisiana. The exception to this trend was at Grand Terre/Queen Bess, the site closest to the mouth of the estuary. The minimum size of spotted seatrout collected along the marsh edge at Grand Terre/Queen Bess was $19.5 \mathrm{~cm}$ SL, and a relatively large number of large gravid females were collected there resulting in a higher mean standard length along the marsh edge habitat at this site. Spotted seatrout are known to spawn near the mouth of the estuary in close proximity to barrier islands and the passes between them connecting the estuary to the Gulf of Mexico [48], thus it is not surprising that we caught large females in this region of $\mathrm{Ba}-$ rataria Bay.

Spotted seatrout are known to spend much of their life cycle near or in estuaries, which provide habitat for all early life stages, juveniles and adults [31]. Spotted seatrout in this study were generally larger in the higher salinity waters near the mouth of the estuary, with the smallest spotted seatrout at the Grand Terre/Queen Bess site measuring $17.1 \mathrm{~cm}$ SL. This compares to a minimum size of $9.3 \mathrm{~cm}$ and $11.0 \mathrm{~cm} \mathrm{SL}$ at Manilla Village and Fisherman's Point, respectively. Thus it may be that more mature, larger spotted seatrout are closer to the mouth of the estuary while the younger spotted seatrout are further up in the estuary, as observed in this study. Helser et al. [49] also found that the size of spotted seatrout was not uniform across all estuarine zones at some times in the year. They found that the abundance of recruit and spawner spotted seatrout were greatest in the lower estuarine zone (15-30 ppt) during the spawning season (MayAugust). When spawning was complete (SeptemberDecember), spawners were uniformly distributed across the estuary while the new recruits were more abundant in the upper estuary (0-9 ppt).

While there was little difference in the ability to predict the presence of spotted seatrout among the different habitat types, our analyses predicted that they were more likely to be found over oyster shell and soft bottom habitats than near the marsh edge habitat. Spotted seatrout are highly mobile and these results likely reflect that these seatrout are moving among habitat types while foraging. This is supported by a diet study of the spotted seatrout collected during this study by Russell [50], which found prey items commonly associated with one particular habitat type in the stomachs of spotted seatrout collected over another habitat type. The probability of detecting a spotted seatrout was highest in the warmest months of the year, May through October, although it was possible to encounter a spotted seatrout between November and April. Moreover, spotted seatrout were predicted to be most likely found over oyster shell or soft bottom, when the water temperature was $24.0^{\circ} \mathrm{C}$ and greater. This is likely also the best time and place to catch a large spotted seatrout, given that larger spotted seatrout were collected when the water temperatures were relatively high.

\section{CONCLUSION}

This study has demonstrated that identifying which habitats are essential for spotted seatrout may not be possible based on the first few guidelines provided by the National Marine Fisheries Service. This study illustrates that the habitat preference of spotted seatrout is not easily defined by habitat type alone, but rather that their distribution, relative abundance, biomass and length distribution are more likely determined by a combination of habitat type and abiotic variables. Their relative abundance increased as water temperature and salinity increased, although there appears to be little preference of oyster shell over soft bottom or marsh edge habitats by adult spotted seatrout. However, smaller spotted seatrout were generally more abundant near the marsh edge habitat at some sampling sites. Therefore, while it is difficult to define any of these habitats individually as essential for spotted seatrout, and given that these habitats are not isolated units, it is likely that together these habitats make up an ecosystem that is important for spotted seatrout. While the concept that both habitat structure and abiotic properties of the water work in concert to define the environment used by estuarine species is not new [8], this ap- 
proach is seldom taken into consideration as a need to ensure future fisheries productivity. These results reinforce the need to manage estuarine species spatially rather than on the concept of EFH, which for many species may now be a bankrupt paradigm. Moreover, given that habitat management may be better served by conserving habitat function than just form [12], restoration efforts to restore the wetlands in coastal Louisiana will likely better serve the estuarine fishes by maintaining the integrity of this important ecosystem, while efforts to build artificial habitats alone may not result in anticipated benefits. While treatments in this study were not replicated and therefore caution should be used when extrapolating results to areas other than those sampled during this study [38], this study demonstrates the importance of an ecosystem approach to fisheries management. In addition, collection of data using multiple gears that effectively sample at a variety of spatial scales will refine our ability to consider spatial data when developing management strategies in Barataria Bay and elsewhere. For more information about the other contemporaneous EFH studies included in this cooperative project between the Louisiana Department of Wildlife and Fisheries and Louisiana State University please see $[47,50-53]$.

\section{ACKNOWLEDGEMENTS}

This study was funded by the Sport Fish Restoration Fund through the Louisiana Department of Wildlife and Fisheries. The authors would like to thank Dr. Charles Wilson, David Neiland, Randy Pausina, Yvonne Allen, Kevin Boswell, Gary Peterson, Aaron Podey and Micah Russell for their participation in this study.

\section{REFERENCES}

[1] Dahl TE. Status and trends of wetlands in the conterminous United States 1986 to 1997. U.S. Department of the Interior: Fish and Wildlife Service: Washington D.C. 2000.

[2] Field DW, Reyer A, Genovese P, Shearer B. Coastal wetlands of the United States-An accounting of a valuable national resource. Strategic Assessment Branch, Ocean Assessments Division: Office of Oceanography and Marine Assessment: National Ocean Service: National Oceanic and Atmospheric Administration: Rockville, MD 1991.

[3] Barras JA, Bourgeois PE, Handley LR. Land loss in coastal Louisiana 1956-90. National Biological Survey, National Wetlands Research Center Open File Report 1994; No 94/01.

[4] Boesch DF, Turner RE. Dependence of fishery species on salt marshes: the role of food and refuge. Estuaries 1984; 7(Pt 4A): 460-8.

[5] Baltz DM, Rakocinski C, Fleeger JW. Microhabitat use by marshedge fishes in a Louisiana estuary. Environ Biol Fishes 1993; 36: 109-26.

[6] Peterson GW, Turner RE. The value of salt marsh edge vs. interior as a habitat for fish and decapod crustaceans in a Louisiana salt marsh. Estuaries 1994; 17(Pt 1B): 235-62.

[7] Minello TJ. Nekton densities in shallow estuarine habitats of Texas and Louisiana and the identification of essential fish habitat. Am Fish Soc Symp 1999; 22: 43-75.

[8] Peterson MS. Conceptual view of environmental-habitatproduction linkages in tidal-river estuaries. Rev Fish Sci 2003; 11: 291-313.

[9] Chesney EJ, Baltz DM, Thomas GR. Louisiana estuarine and coastal fisheries and habitats: perspectives from a fish's eye view. Ecol Appl 2000; 10: 350-66.

[10] Bell SS, McCoy ED, Mushinsky HR. Habitat structure; the physical arrangement of objects in space. Chapman and Hall: London 1991.
[11] DeLong AK, Collie JS. Defining essential fish habitat: A modelbased approach. Rhode Island Sea Grant, Narragansett, RI 2004.

[12] Hood WG. Landscape allometry and prediction in estuarine ecology: Linking landform scaling to ecological patterns and processes. Estuaries Coasts 2007; 30: 895-900.

[13] Partyka ML, Peterson MS. Habitat quality and salt marsh species assemblages along an anthropogenic estuarine landscape. J Coast Res 2008; 24: 1570-82.

[14] Zimmerman RJ, Minello TJ, Baumer TJ, Catiglione MC. Oyster reef as habitat for estuarine macrofauna. National Oceanic and Atmospheric Administration Technical Memorandum, National Marine Fisheries Service: Southeast Fisheries Science Center: Galveston, Texas 1989.

[15] Coen LD, Luckenbach MW, Breitburg DL. The role of oyster reefs as essential fish habitat: a review of current knowledge and some new perspectives. Am Fish Soc Symp 1999; 22: 438-54

[16] Harding JM, Mann R. Diet and habitat use by bluefish, Pomatomus saltatrix, in Chesapeake Bay estuary. Environ Biol Fishes 2001; 60: 401-9.

[17] Dunson WA, Travis J. The role of abiotic factors in community organization. Am Nat 1991; 138(5): 1067-91.

[18] Rakocinski CF, Baltz DM, Fleeger JW. Correspondence between environmental gradients and the community structure of marshedge fishes in a Louisiana estuary. Mar Ecol Prog Ser 1992; 80: $135-48$.

[19] Rozas LP, Zimmerman RJ. Small-scale patterns of nekton use among marsh and adjacent shallow nonvegetated areas of the Galveston Bay estuary, Texas, United States. Mar Ecol Prog Ser 2000; 193: 217-39.

[20] Granados-Diesldorff P, Baltz DM. Habitat use by nekton along a stream-order gradient in a Louisiana Estuary. Estuaries Coasts 2008; 31: 572-83.

[21] Zimmerman RJ, Minello TJ, Zomora Jr. G. Selection of vegetated habitat by brown shrimp, Penaeus aztecus, in a Galveston Bay salt marsh. Fish Bull 1984; 82: 325-36.

[22] Lehnert RL, Allen DM. Nekton use of subtidal shell in a southeastern U.S. estuary. Estuaries 2002; 25(Pt 5): 1015-24.

[23] Plunket J, LaPeyre MK. Oyster beds as fish and macroinvertebrate habitat in Barataria Bay, Louisiana. Bull Mar Sci 2005; 77(Pt 1): 155-64.

[24] Stunz GW, Minello TJ. Habitat-related predation on juvenile wildcaught and hatchery-reared red drum, Sciaenops ocellatus (Linnaeus). J Exp Mar Biol Ecol 2001; 260: 13-25.

[25] Stunz GW, Minello TJ, Levin PS. A comparison of early juvenile red drum densities among various habitat types in Galveston Bay, Texas. Estuaries 2002; 25(Pt 1): 76-85.

[26] Armstrong, CW, Falk-Petersen, J. Habitat-fisheries interactions: a missing link? ICES J Mar Sci 2008; 65: 817-21.

[27] Wilen, JE. Spatial management of fisheries. Mar Resour Econ 2004; 19: 17-9

[28] Horst J. Speckled trout facts. Louisiana Fisheries Resources and Publications Fact Sheets. Louisiana Sea Grant: updated [2003 June, accessed 2009 October 28]. Available from: http://www.seagrantfish.lsu.edu/resources/factsheets/speckledtrout. htm.

[29] National Marine Fisheries Service, Fisheries Statistics Division, Silver Spring, MD; updated [2009, accessed 2009 October 28]. Available from: http://www.st.nmfs.noaa.gov/st1/index.html.

[30] Bortone SA. In: Bortone SA, Ed. Biology of Spotted Seatrout. London: CRC Press 2003; pp. 1-3.

[31] Tabb DC. The estuary as a habitat for spotted seatrout Cynoscion nebulosus. Am Fish Soc (Special Publication) 1966; 3: 59-67.

[32] Perret WS, Weaver JE, Williams RO, et al. Fishery profiles of red drum and spotted seatrout. Gulf States Marine Fisheries Commission Report 1980; No. 6.

[33] Lassuy DR. Species profiles: life histories and environmental requirements (Gulf of Mexico) - spotted seatrout. United States Army Corps of engineers, TR EL-82-4. United States Fish and Wildlife Service, Division of Biological Services 1983. Report No. FWS/OBS-82/11.4.

[34] Baltz DM, Fleeger JW, Rakocinski CF, McCall JN. Food, density and microhabitat: factors affecting growth and recruitment potential of juvenile saltmarsh fishes. Environ Biol Fish 1998; 53: 89103.

[35] Bortone SA. In: Bortone SA, Ed. Biology of Spotted Seatrout, II Marine Biology Series. London: CRC Press 2003; pp. 297-300. 
[36] Conner WH, Day J.W. In: Conner WH, Day JW, Eds. Description of the Basin: The ecology of Barataria basin, Louisiana. U.S. Fish and Wildlife Service Biological Report 85(7.13) 1987; 1-7.

[37] SAS Institute Inc., Version 9.0. Cary, North Carolina, USA. 2002.

[38] Hurlbert SH. Pseudoreplication and the design of ecological experiments. Ecol Monogr 1984; 54(Pt 2): 187-211.

[39] Jordan F, Bartolini M, Nelson C, Patterson PE, Soulen HL. Risk of predation affects habitat selection by the pinfish Lagadon rhomboides (Linnaeus). J Exp Mar Biol Ecol 1996; 208: 45-56.

[40] Craig JK, Crowder LB. In Weinstein MP, Kreeger DA, Eds. Concepts and Controversies in Tidal Marsh Ecology. California Sea Grant: Kluwer Academic Publishers 2000; pp. 241-61.

[41] Kostecki PT, Fore PL. Habitat suitability index models: spotted seatrout. United States Fish and Wildlife Service, Division of Biological Services. Washington, District of Columbia 1984; No. FWS/OBS-82/10.75.

[42] Clark DC, Morrison W, Christensen JD, Monaco ME, Coyne MS. In: Bortone SA, Ed. Biology of Spotted Seatrout, II Marine Biology Series. CRC Press 2003; 247-65.

[43] Hubert WA. In Murphy BR and Willis DW Eds. Fisheries Techniques, 2nd ed. Am Fish Soc 1996; 157-92.

[44] Hubert WA, O'Shea DT. Use of spatial resources by fishes in Grayrocks Reservoir, Wyoming. J Freshwater Ecol 1992; 7: 21925.

[45] Persson L, Crowder LB. In Jeppesen E, Ma S, Mo S, Christoffersen $\mathrm{K}$. Eds. The structuring role of submerged macrophytes in lakes. USA: Springer-Verlag 1998; pp. 3-23.
[46] Werner EE, Gilliam JF. The ontogenetic niche and species interactions in size structured populations. Ann Rev Ecol Syst 1984; 15: 393-425.

[47] Birdsong TW. Complexity and nekton use of marsh edge habitats in Barataria Bay, Louisiana. MS. Thesis, Louisiana State University, Baton Rouge, LA 2004.

[48] Saucier MH, Baltz DM. Spawning site selection by spotted seatrout, Cynoscion nebulosus, and black drum, Pogonias cromis, in Louisiana. Environ Biol Fish 1993; 36: 257-72.

[49] Helser TE, Condrey RE, Geaghan JP. Spotted seatrout distribution in four coastal Louisiana estuaries. Trans Am Fish Soc 1993; 122: 99-111.

[50] Russell M. Spotted seatrout (Cynoscion nebulosus) and pinfish (Lagadon rhomboides) dietary analysis according to habitat type. MS. Thesis, Louisiana State University, Baton Rouge, LA 2004.

[51] Boswell KM. Quantifying Changes in Fish Habitat Use in Coastal Waters of Louisiana, USA: A Hydroacoustic Approach. Ph.D. Dissertation, Louisiana State University, Baton Rouge, LA 2006.

[52] Caudill MC. Nekton Utilization of Black Mangrove (Avicennia germinans) and Smooth Cordgrass (Spartina alterniflora) Sites in Southwestern Caminada Bay, Louisiana. MS. Thesis, Louisiana State University, Baton Rouge, LA 2005.

[53] MacRae PSD. A Community Approach to Identifying Essential Fish Habitat of Spotted Seatrout, Cynoscion nebulosus, in Barataria Bay, Louisiana. Ph.D. Dissertation, Louisiana State University, Baton Rouge, LA 2006.

Received: October 29, 2009

Revised: March 10, 2010

Accepted: April 05, 2010

(c) MacRae and Cowan; Licensee Bentham Open.

This is an open access article licensed under the terms of the Creative Commons Attribution Non-Commercial License (http://creativecommons.org/licenses/by-nc/3.0/) which permits unrestricted, non-commercial use, distribution and reproduction in any medium, provided the work is properly cited. 